\title{
Interventional Radiological Management of Prehepatic Obstruction of the Splanchnic Venous System
}

\author{
Aslihan Semiz-Oysu • Inger Keussen • \\ Wojciech Cwikiel
}

Published online: 18 October 2007

(C) Springer Science+Business Media, LLC 2007

\section{Erratum to: Cardiovasc Intervent Radiol}

DOI 10.1007/s00270-007-9097-3

Re: Cardiovasc Intervent Radiol (2007) 30:688-695-The title of this article was printed incorrectly. It appears correctly below:

Interventional Radiological Management of Prehepatic Obstruction of the Splanchnic Venous System

The online version of the original article can be found under doi: 10.1007/s00270-007-9097-3

\footnotetext{
A. Semiz-Oysu

Department of Radiology, Siyami Ersek Thoracic and

Cardiovascular Surgery Training and Research Center, Istanbul,

Turkey

A. Semiz-Oysu ( $\varangle)$

Siyami Ersek Gogus Kalp ve Damar Cerrahisi Egitim ve

Arastirma Hastanesi, Radyoloji Bolumu, Tibbiye Caddesi,

Haydarpasa, Istanbul, Turkey

e-mail: asoysu@gmail.com

I. Keussen

Department of Radiology, Malmoe University Hospital,

Malmoe, Sweden

W. Cwikiel

Department of Radiology, University of Michigan Hospital, Ann

Arbor, MI 48109, USA
} 